\title{
心胸郭比拡大を伴う維持血液透析症例における 心機能の心エコー図による解析
}

\author{
新田孝作湯村和子大図弘之寺田嘉文 \\ 沖本 錦 吾* 大場 孝* 宮島 さや子* 蒲 谷 堯* \\ 二 瓶 宏 \\ 東京女子医科大学第 4 内科 南千住病院*
}

key words：慢性血液透析，心胸郭比拡大，心エコー，心機能，僧房弁閉鎖不全

〈要旨〉

血液透析導入後の各時期における心機能を心エコーにより評価するのを目的とした．適切な標準体重の設定にもか かわらず，3 か月間以上にわたって心胸郭比（CTR）の拡大を伴う慢性血液透析患者を対象とした。透析継続期間に より A 群 ( 1 年以上, 5 年末満), B 群 ( 5 年以上, 10 年末満) およびC 群 (10 年以上) に分け, Mモード心エコー 法により心機能を, ドップラー法で僧房弁および大動脈弁疾患の有無を検討した. 体重増加率, 平均血圧と CTRに 関しては各群間で有意差はなかった。心電図の $V_{1} S+V_{5} R$ から算定した左室肥大の程度は $A$ 群に比し，C群で有意に 増大していた。機能では, A群に比し C 群で左室拡張末期径が低下し, 駆出率は増加していた。 心室中隔 $>15 \mathrm{~mm}$ および左室拡張末期径 $<50 \mathrm{~mm}$ の肥厚型心筋症タイプの割合が透析年数が進むにつれ増加した。この肥厚型心筋症夕 イプの症例には僧房弁および大動脈弁閉鎖不全を合併する頻度が高かった。このように, 透析年数とともに左室収縮 能は改善傾向を示すにもかかわらず, 肥厚型心筋症タイプの合併が増加するため, 心エコーによる経時的観察と適切 な治療が望まれる。

\section{Echocardiographic study of cardiac function in maintenance hemodialysis patients with an enlarged cardiothoracic ratio (CTR)}

Kosaku Nitta, Wako Yumura, Hiroyuki Ozu, Yoshifumi Terada*, Kingo Okimoto*, Takashi Oba*, Sayako Miyajima*, Takashi Kabaya*, Hiroshi Nihei

Department of Medicine, Kidney Center, Tokyo Women's Medical College and Minami Senjyu Hospital*

The aim of the present study was to investigate the cardiac functions of hemodialysis patients at various times after the beginning of hemodialysis. The subjects of this study were maintenance hemodialysis patients with an enlarged CTR despite an adequate dry weight. They were divided into three groups according to the duration of hemodialysis (group A : no less than 1 year-less than 5 years; group B : 5 years-less than 10 years; group C : 10 years or longer). There were no significant differences in percent body weight change, mean blood pressure or CTR among the three groups. The grade of left ventricular hypertrophy estimated by electrocardiography $\left(\mathrm{V}_{1} \mathrm{~S}+\right.$ $V_{5} R$ ) was larger in group $C$ patients than in group $A$ patients. In terms of cardiac functions, a decreased left ventricular end-diastolic diameter (LVDd) and an increased ejection fraction were apparent in group C patients as compared with those in group A. The occurrence of hypertrophic cardiomyopathy (intraventricular septum thickness $>15 \mathrm{~mm}, \mathrm{LVDd}<50 \mathrm{~mm}$ ) gradually increased in proportion to the duration of hemodialysis. The patients with hypertrophic cardiomyopathy had complications such as mitral and/or aortic regurgitation. Therefore, it is important to follow the cardiac functions of hemodialysis patients with enlarged CTR using echocardiography.

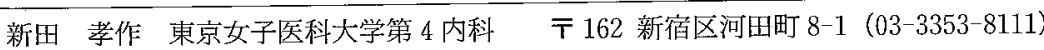

【受付: 平成 6 年 1 月 11 日, 受理 : 平成 6 年 4 月 30 日] 


\section{緒言}

維持血液透析患者の予後が伸びつつあるにもかかわら ず，死因の第 1 位は依然として心不全であり，その割合 がむしろ増加する傾向にある 化が進んだことと糖尿病性腎症から導入される患者数が 増加したことに起因していると考えられる，従って，血 液透析患者の心機能を経時的に評価する必要性が高まっ ている゙2.

今まで正常者と血液透析患者の心機能の比較に関する 報告はあるが，心胸郭比 (CTR) 拡大を伴う長期維持透 析患者の心機能を透析年数別に比較検討した報告はな い. 今回，筆者らは心エコーを用いて適正な標準体重の 設定にもかかわらず, CTR の拡大を伴う維持透析患者の 心機能を評価するとともに，僧房弁および大動脈弁疾患 の有無を検討したので報告する。

\section{対象と方法}

対象は, 先天性心臟病および心臓弁膜症などの器質的 心疾患を有さず，適正な標準体重の設定にもかかからず CTR が少なくとも 3 か月間 $50 \%$ 以上の血液透析症例 29 例 (男性 11 例，女性 18 例，平均年齢 60 歳）である. 原 疾患好慢性系球体腎炎 26 例, 糖尿病 2 例, 急性腎不全 1 例である。透析導入前の高血圧の既往は明らかでなく， 導入後は降圧剂の投与により比較的血圧がコントロール されている症例を選別した。透析の継続期間により A 群 ( 1 年以上, 5 年未満 10 例, 平均年齢 59 歳)，B群 ( 5 年以上, 10 年末満 9 例, 平均年齢 66 歳) および C 群 (10 年以上 10 例, 平均年齢 57 歳）の 3 群に分類した。ほ 同じ時期に血圧 (平均血圧) 測定，標準 12 誘導心電図， 胸部 $\mathrm{X}$ 線および心エコーを施行した。体重增加率 $(\triangle \mathrm{BW})$ は透析間の体重増加 ( 3 加月間の平均)/標準体重 $\times 100 \%$ で求めた。心機能はMモードにて左室拡張末期 径 (LVDd) 扔よび収縮末期径 (LVDs), 心係数 (CI), 駆 出率 $(\% \mathrm{EF})$, 心室中隔壁厚 (IVS) ならびに左室後壁厚 (LVPW) について各群間で比較した。 また, Parfrey の 報告 ${ }^{3}$ に従って LVDd, EF および IVS 值より拡張型心 筋症タイプと肥厚型心筋症タイプの割合を算定した。な
お, 母集団の比較として, 適正な標準体重の設定で CTR が50\%以下にコントロールされる症例では, 心エコーに より IVS と PVCW の肥厚がなく, LVDd が正常範囲 内にあった。一方，ドップラー法で僧房弁扔よび大動脈 弁疾患の有無を検討した。

各指標值は平均值士標準偏差で表示した。統計学的検 討にはANOVA を用い，5\%以下の危険率をもって有 意と判定した.

\section{結果}

1. 対象症例のプロフィール

表 1 に示すように，血液透析導入後の経過年数別に分 けた 3 群の年齢はそれぞれA群：59.2 13.4 歳，B群： $66.2 \pm 6.4$ 歳沾よびC 群: $56.5 \pm 8.6$ 歳と有意差を認め

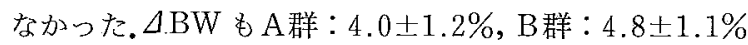
およびC群: $4.3 \pm 1.0 \%$ と有意差がなく, 平均血圧と CTRも 3 群間で有意差を認めなかった。しかし，心電図 から算定した左室肥大 $(\mathrm{LVH})$ の指標である $\mathrm{V}_{1} \mathrm{~S}+\mathrm{V}_{5} \mathrm{R}$ はA群： $40.0 \pm 13.7 \mathrm{~mm}, \mathrm{~B}$ 群: $30.9 \pm 8.9 \mathrm{~mm}$ 抢よび C

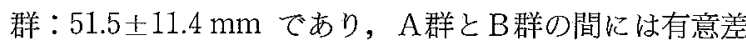
を認めなかったが，C群はA群および $\mathrm{B}$ 群に比し有意に LVH の程度が增大していた（ $\mathrm{p}<0.01 ） 。 な お ， C$ 群に おける高血圧症の既往歴は，A群および $\mathrm{B}$ 群と比較して 差を認めなかった。

\section{2. 心機能}

1) LVDd \& LVDs (図 1)

LVDd はA 群: $57.2 \pm 11.6 \mathrm{~mm}, \mathrm{~B}$ 群: $50.6 \pm 5.1 \mathrm{~mm}$, C群： $49.2 \pm 4.4 \mathrm{~mm}$ で, C群ではA 群に比し有意に低下 していた $(\mathrm{p}<0.05)$. LVDsはA群 : $39.1 \pm 11.0 \mathrm{~mm}$, B 群 : $31.0 \pm 6.3 \mathrm{~mm}, \mathrm{C}$ 群 : $31.7 \pm 6.5 \mathrm{~mm}$ と各群間に有意 差を認めなかった。

2) $\mathrm{EF} \& \mathrm{CI}$ (図 2)

$\mathrm{EF}$ は A 群 : $57.0 \pm 13.7 \%, \mathrm{~B}$ 群: $70.0 \pm 8.4 \%, \mathrm{C}$ 群: $67.7 \pm 8.5 \%$ で, A群に比しB群抢よびC群で有意に 増加していた $(\mathrm{p}<0.05)$. CI はA 群: $4.8 \pm 1.7 \mathrm{ml} / \mathrm{min} /$ $\mathrm{m}^{2}$, B群 : $5.1 \pm 1.9 \mathrm{ml} / \mathrm{min} / \mathrm{m}^{2}$, C群 : $4.2 \pm 1.2 \mathrm{ml} / \mathrm{min} /$ $\mathrm{m}^{2}$ と各群間で有意差を認めなかった。

表 1 対象患者のプロフィール

\begin{tabular}{cccccccc}
\hline $\begin{array}{c}\text { Group } \\
(\mathrm{n})\end{array}$ & $\begin{array}{c}\text { Age } \\
(\mathrm{yr})\end{array}$ & $\begin{array}{c}\text { Sex } \\
(\mathrm{M}: \mathrm{F})\end{array}$ & $\begin{array}{c}\text { Duration } \\
\text { of HD }(\mathrm{yr})\end{array}$ & $\begin{array}{c}\Delta \mathrm{BW} \\
(\%)\end{array}$ & $\begin{array}{c}\text { Mean BP } \\
(\mathrm{mmHg})\end{array}$ & $\begin{array}{c}\text { CTR } \\
(\%)\end{array}$ & $\begin{array}{c}\text { ECG } \\
\mathrm{V}_{1} \mathrm{~S}+\mathrm{V}_{5} \mathrm{R}(\mathrm{mm})\end{array}$ \\
\hline $\begin{array}{c}\mathrm{A} \\
(11)\end{array}$ & $59.2 \pm 13.4$ & $3: 8$ & $2.6 \pm 1.2$ & $4.0 \pm 1.2$ & $118.1 \pm 8.4$ & $54.6 \pm 3.8$ & $48.1 \pm 16.4$ \\
\hline $\begin{array}{c}\mathrm{B} \\
(8)\end{array}$ & $66.2 \pm 6.4$ & $1: 7$ & $7.0 \pm 1.1$ & $4.8 \pm 1.1$ & $116.0 \pm 3.7$ & $57.1 \pm 4.7$ & $35.0 \pm 14.7$ \\
\hline $\begin{array}{c}\mathrm{C} \\
(10)\end{array}$ & $56.5 \pm 8.6$ & $6: 4$ & $13.6 \pm 3.1$ & $4.3 \pm 1.0$ & $115.0 \pm 10.6$ & $54.9 \pm 3.9$ & $53.5 \pm 12.5^{*}$ \\
\hline
\end{tabular}

${ }^{*} \mathrm{p}<0.01$ vs Groups $A$ and $B$ 


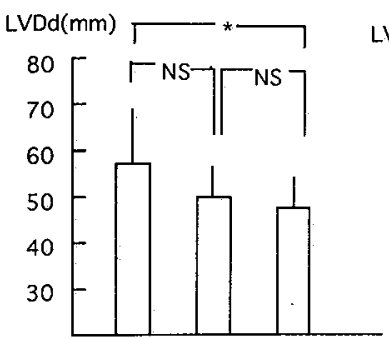

A B C

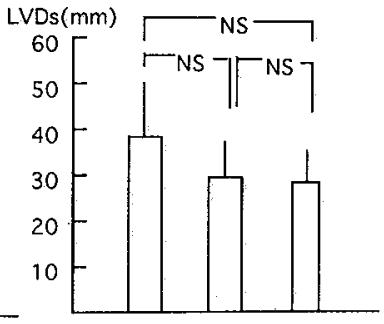

A B $C$
図 1 慢性透析患者の左室拡張末期径 (LVDd) と左室収縮末期径 (LVDs) $* \mathrm{p}<0.05$
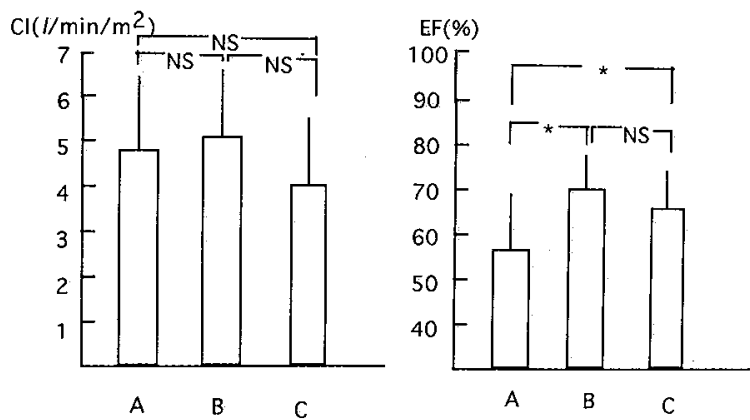

図 2 慢性透析患者の左心収縮能 $\mathrm{CI}$ ：心係数, $\mathrm{EF}$ : 駆出率 $* \mathrm{p}<0.05$

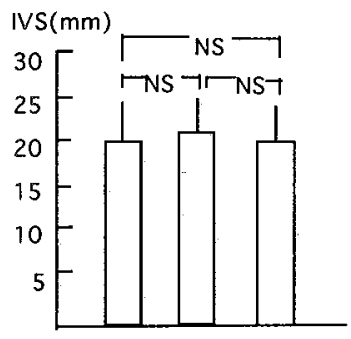

A B $C$

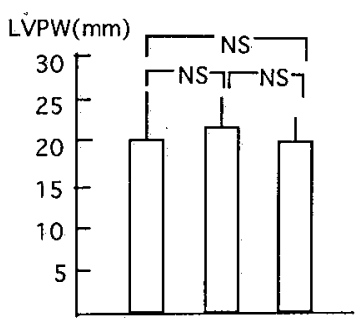

A B $C$
図 3 慢性透析患者の心室中隔壁厚 (IVS) と左 心室後壁厚 (LVPW)

\section{3 ) IVS \& LVPW (図 3)}

IVS はA 群 : $19.9 \pm 4.6 \mathrm{~mm}, \mathrm{~B}$ 群 : $22.3 \pm 3.8 \mathrm{~mm}, \mathrm{C}$ 群: $20.4 \pm 3.5 \mathrm{~mm}$ で, LVPW はA群 : $21.8 \pm 6.4 \mathrm{~mm}, \mathrm{~B}$ 群: $22.0 \pm 3.3 \mathrm{~mm}, \mathrm{C}$ 群 : $21.2 \pm 2.7 \mathrm{~mm}$ と各群間に有意 差を認めなかった。

\section{4) LVDd, EF \& IVS}

拡張型心筋症タイプ $(\mathrm{EF}<55 \%, \mathrm{LVDd}>55 \mathrm{~mm})$ の 割合はA群では 11 例中 2 例 (18.2\%)であり，B群扔よ びC群では認められなかった. 肥厚型心筋症タイプ (IVS > $15 \mathrm{~mm}, \mathrm{LVDd}<50 \mathrm{~mm}$ ) の割合はA群：11 例中 3 例 $(27.3 \%)$, B群：8例中 4 例 $(50 \%)$, C群：10 例
表 2 慢性透析患者に抢ける僧房弁閉鎖不全 (MR) と大動脈弁閉鎖不全 (AR) の程度 + ; 軽症, ++ ; 中等度, +++ ; 重症

\begin{tabular}{|c|c|c|c|}
\hline & & $\mathrm{AR}$ & MR \\
\hline \multirow{11}{*}{ A } & 1 & - & + \\
\hline & 2 & - & - \\
\hline & 3 & + & - \\
\hline & 4 & + & + \\
\hline & 5 & - & + \\
\hline & 6 & - & + \\
\hline & 7 & - & + \\
\hline & 8 & + or ++ & - \\
\hline & 9 & - & + or $t+$ \\
\hline & 10 & - & +++ \\
\hline & 11 & +++ & + \\
\hline \multirow{8}{*}{ B } & 1 & - & + \\
\hline & 2 & - & - \\
\hline & 3 & - & + \\
\hline & 4 & + or ++ & ++ \\
\hline & 5 & - & + \\
\hline & 6 & + & + \\
\hline & 7 & - & ++ \\
\hline & 8 & - & - \\
\hline \multirow{10}{*}{ C } & 1 & - & +++ \\
\hline & 2 & - & + \\
\hline & 3 & ++ & ++ \\
\hline & 4 & +++ & - \\
\hline & 5 & ++ & + \\
\hline & 6 & - & - \\
\hline & 7 & - & + \\
\hline & 8 & - & + \\
\hline & 9 & ++ & + or ++ \\
\hline & 10 & - & + \\
\hline
\end{tabular}

中 6 例 $(60 \%)$ であった。

\section{3. 僧房弁および大動脈弁疾患の有無（表 2)}

僧房弁閉鎖不全を認める症例は，A群：11例中 8 例 $(72.7 \%)$, B群：8例中 6 例 (75\%), C群：10 例中 8 例 (80\%)であった. 大動脈弁閉鎖不全を認める症例は，A 群：11 例中 4 例 $(36.4 \%)$, B群：8例中 2 例 (25\%), C群：10 例中 4 例（40\%）であった。

\section{考察}

維持透析患者の心機能の評価については, 現在までい くつかの報告があるが，いまだ一致した見解が得られて いない ${ }^{4 \sim 7)}$. その理由として，血液透析自体が患者の循環 動態に大きな影響を及ぼすこと，慢性腎不全による心病 変が多彩であること，招よび検查施行時の透析条件の相 違などが考えられる。そこで，今回は血液透析導入後の 各時期における心機能を評価する目的で, CTR が少なく とも 3 か月間 $50 \%$ 以上で, 心肥大が予想される症例を選 
び，透析導入後の経過期間により 3 群に分け，その心機 能と僧房弁および大動脈弁疾患の有無を検討した。

対象症例の $\Delta \mathrm{BW}$, 平均血圧, CTR は透析年数により 有意差を認めなかった，心電図上の $V_{1} S+V_{5} R$ による LVH の程度は透析年数 10 年以上のC 群で有意に増大 していた。 また，他に有意差を認めたのは透析導入 5 年 未満の群に比し, 導入 10 年以上の群で LVDd が低下し, EF が増加していた点である。これは，透析年数が進むに つれて左室収縮能が改善していることを示す。しかし， 透析導入後 10 年以上経過しているC群は, 年齢的に A 群 より 3 歳, B群より 9 歳若く, 透析の経過年数別の比較 は導入時の年齢が同じ集団を選別する必要があると考光 られた。一方, すべての症例は血圧, 透析効率および臨 床症状などより標準体重が設定されており，心機能測定 時の透析効率，へマトクリット值および IVS や LVPW 值に有意差を認めていない。しかし, IVS ゃ LVDd 值 からみた肥厚型心筋症タイプの発症は透析年数が進むに つれて増加する傾向を認め，これらの症例には僧房弁や 大動脈弁の閉鎖不全症を合併する頻度が高かった。それ にもかかわらず，これらの症例はジギタリス製剂，カル シウム拮抗剤およびアンギオテンシン変換醭素阻害剤の 投与により血圧のコントロールがよく, 心収縮能の上昇 につながったものと考元れる。

筒井らの報告4では，透析患者 131 例を対象に心工 コーで心機能を評価したところ, 左室拡張 $(\geqq 5.6 \mathrm{~cm})$ は $14.7 \%$, 左室壁肥厚 $(\geqq 1.3 \mathrm{~cm})$ 㹥 $44.6 \%$ にみられ, 左 心系機能の低下を示す $\mathrm{EF}$ 低下（ $555 \%$ ）は $13.2 \%$ ，CI 低下 ( $\left.\leqq 2.3 \mathrm{l} / \mathrm{min} / \mathrm{m}^{2}\right)$ は $9.1 \%$ みられたという。約 10\%の患者に低拍出性の心不全傾向を示す障害が認めら れることになる。一方, 左室の拡張能に関して，岡田 ${ }^{5}$ は Mモード心エコーにて急速充満速度, 急速充満期に扮け る平均左室内周伸展速度の低下を認め, 拡張能に異常が あると報告している。その原因としては, LVH 自体の影 響による左室腔のコンプライアンス，心筋機能，線維芽 細胞の増殖による壁コンプライアンスの変化によると考 元られる。

長期透析による心機能の変化については, 改善, 不変, 悪化と種々の評価が報告されている.西村ら ${ }^{6}$ は, 透析歴 1 年以内, $1 \sim 5$ 年, 5 年以上の 3 群に分けて心機能の 推移を検討している。透析開始 1 年後には心筋厚が減少 し，透析前の心筋病変に対する透析の効果が現れ，5年 以上では \%FS, CI の増加など左室収縮能の改善を認め ている.しかし, London ${ }^{7)} 30$ か月以上観察した 74 例 の透析患者にて心室腔の拡大，心筋の肥厚执よび心収縮
能の低下などの異常所見の進行を報告している.

Parfrey $ら^{3)}$ は, 透析患者で心不全を示す症例を心工 コーで検討している。拡張型心筋症タイプ $(\mathrm{EF}<55 \%$, LVDd $\geqq 5.5 \mathrm{~cm})$ が $18 \%$ にみら，年齢, 副甲状腺機能元 進症，喫煙が危険因子であり，血管拡張薬やジギタリス 製剤が有効であると報告している，また，肥厚型高拍出 性心筋症タイプ (左室壁厚 $\geqq 1.4 \mathrm{~cm}, \operatorname{LVDd}<5.0 \mathrm{~cm}$, $\mathrm{EF}>70 \%$ ) $11 \%$ に認め，危険因子として高血圧や副甲 状腺機能立進症が疑われた。 $\beta$ 遮断薬や交感神経抑制薬 が有効であり，透析による除水は心筋収縮を強め血圧低 下を伃さとしている．この心不全状態は透析患者の予 後を悪化させ，特に後者の方が顕著なため早期に心工 コーによる診断と的確な治療が必要と考えられる。また, 可能であれば，同一症例の心機能の経過を年次ごとに追 跡する必要があると考光られた。

\section{結論}

CTR 拡大を伴亏慢性血液透析患者に扔いては, 透析年 数とともに肥厚型心筋症タイプおよび僧房弁や大動脈弁 の開鎖不全を併発することが多く，経時的に心機能や弁 膜症の有無を心エコーで検討することは，適切な治療を 考える上で参考になる。

\section{文献}

1）日本透析療法学会：わが国の慢性透析療法の現況 (1991 年現在)。透析会誌 $26: 17-30,1993$

2）由宇宏貴，黑岩昭夫：維持透析患者の心エコーによ る心機能評価。日本臨床（臨時増刊） $50 ： 475-481$, 1992

3) Parfrey PS, Harnett JD, Griffiths SM, Gault MH, Barre PE : Congestive heart failure in dialysis patients. Arch Intern Med 148: 1519-1525, 1988

4）筒井牧子, 三浦和正，平沢由平：慢性透析患者の心 機能一心エコ一図を中心として一。透析会誌 19 ： 665-671, 1986

5）岡田義信：慢性血液透析患者の心機能のエコー図に 上る解析．日腎会誌 $31 ： 765-774 ， 1989$

6）西村眞人，中西 正，國重 宏，平林正己，保井明 泰, 松沢 誠, 池垣岩夫, 高橋伯夫, 吉村 学: 維 持血液透析例の心機能に関する検討。臨床と研究 $66: 2502-2508,1989$

7) London GM : Cardiovascular function in hemodialysis patients. In "Advances in $\mathrm{Ne}$ phrology” ed Grunfeld JP, Maxwell MH, p 249 -273, Mosby Year Book, Chicago, 1991 